Scientia Agricola

http://dx.doi.org/10.1590/0103-9016-2014-0369

Review

\title{
Cashew cultivation in Guinea-Bissau - risks and challenges of the success of a cash crop
}

Luís Catarino ${ }^{1,2 *}$, Yusufo Menezes ${ }^{3}$, Raul Sardinha ${ }^{4}$

${ }^{1}$ Tropical Research Institute/Tropical Botanic Garden, Trav. Conde da Ribeira, 9 - 1300-142 - Lisboa - Portugal. 2University of Porto/Research Centre for Biodiversity and Genetic Resources, Agricultural Campus of Vairão - 4485601 - Vairão - Portugal.

${ }^{3}$ National Institute of Studies and Research - Complexo

Escolar 14 de Novembro, C.P. 112 - Bissau - Guiné-Bissau.

4Piaget Institute/International Center for Research on

Epistemology and Transdisciplinary Reflection, Av. João

Paulo II, Lote 544-2 $2^{\mathrm{a}}$ 1900-726 - Lisboa, Portugal.

*Corresponding author <Icatarino@iict.pt>

Edited by: Francesco Montemurro

Received April 08, 2014

Accepted March 13, 2015
ABSTRACT: In recent decades a boom in cashew (Anacardium occidentale) cultivation has taken place in Guinea-Bissau, leading to the replacement of traditional slash-and-burn agriculture by a cash crop. As a result, the country is currently one of the world's largest producers of raw cashew nuts and the cashew sector has acquired enormous importance in Guinea-Bissau's economy. Changes induced by the cashew boom at social and environmental levels are yet to be analyzed and understood. The present study provides an account of the process of cashew expansion in Guinea-Bissau, reviews the current situation and discusses its future prospects. The cashew tree was introduced into the country by the Portuguese in the XIXth century, but only effectively expanded in the mid-1980s. It is largely cultivated by small farmers around villages and also plays a role in land ownership, since land tenure practices are linked to the planting of trees. The effects of this cashew boom on habitat fragmentation, fire regimes and biodiversity are still to be assessed. On the other hand, the spread of pests and diseases is becoming a problem. Strong dependence on a single cash crop also renders the country vulnerable to market fluctuations, entailing risks to local producers and the national economy. In the medium term, losses of export earnings can occur, which may impact the living standards and food security of BissauGuineans both in urban and rural areas.

Keywords: West Africa, agroforestry systems, cashew nut, tree crops

\section{Introduction}

\section{The country}

Guinea-Bissau is located in West Africa, between $10^{\circ} 59^{\prime}-12^{\circ} 20^{\prime} \mathrm{N}$ and $13^{\circ} 40^{\prime}-16^{\circ} 43^{\prime} \mathrm{W}$ (Figure 1). According to the National Institute of Statistics and Census, in 2014 1,514,451 inhabitants populated an area of $36,125 \mathrm{~km}^{2}$. Outside of the capital, Bissau, the population is mainly rural and very few services and infrastructures are in place. The climate is tropical, with alternating wet and dry seasons, and the vegetation can be divided into three main zones: (i) littoral (mangroves, palm groves, woodlands and forest); (ii) transitional (mosaic of woodland and savanna woodland; tall grass savanna in the inner valleys); and (iii) interior (woodland, savanna woodland and shrubby or herbaceous steppes). As a consequence of human intervention, mostly shifting agriculture and fire, the most common types of vegetation found in Guinea-Bissau are secondary formations (Catarino et al., 2008). Wildfires are liable to occur every dry season and deforestation was estimated to reach $1 \%$ per year in the period 1990-2000 (FAO, 2014).

\section{Bioecology of Anacardium occidentale L.}

The cashew tree, $A$. occidentale, of the Anacardiaceae family, is an evergreen tree growing to a height of 8-20 m depending on soil characteristics and climate. It normally starts flowering by the third year, attaining full production by the eighth year. The period of full production can last up to 20-30 years and the lifespan of the tree is variable. The nut, which is the true fruit, is a kidney-shaped achene that does not split open after drying. Inside the shell, which contains corrosive oil, is a large curved $2-3 \mathrm{~cm}$ seed, the edible cashew nut. As the nut matures, the peduncle at the base enlarges into a fleshy, bell-shaped, fruitlike structure, popularly known as the false fruit or cashew apple. This thin-skinned edible false fruit has yellow spongy and juicy flesh, which is pleasantly acidic and slightly astringent when eaten raw, but highly astringent when green (Behrens, 1996).

From its origin in northeastern Brazil, A. occidentale spread to South and Central America. The first record of cashew in Africa dates back to the end of the XVIIIth century although Johnson (1973) mentioned that it might have been introduced long before that date. It is now cultivated in many tropical countries mainly for its highly appreciated nuts (Orwa et al., 2009). The cashew tree grows at altitudes of up to $1000 \mathrm{~m}$, in mean annual temperatures ranging from $17-38^{\circ} \mathrm{C}$, and does not tolerate frost. Distribution of rainfall is more important than the amount, and the tree grows in a range of 500-3500 $\mathrm{mm}$ of rainfall. This crop is able to adapt to very dry conditions, as long as its extensive root system has access to soil moisture. It prefers deep and fertile sandy soils but will grow well on most soils except pure clays or soils that are otherwise impermeable, poorly drained or subject to periodic flooding. It fruits well if rains are not abundant during flowering and if the nuts mature during the dry period. With this generic classification, and disregarding the edaphic constraints, all territory 


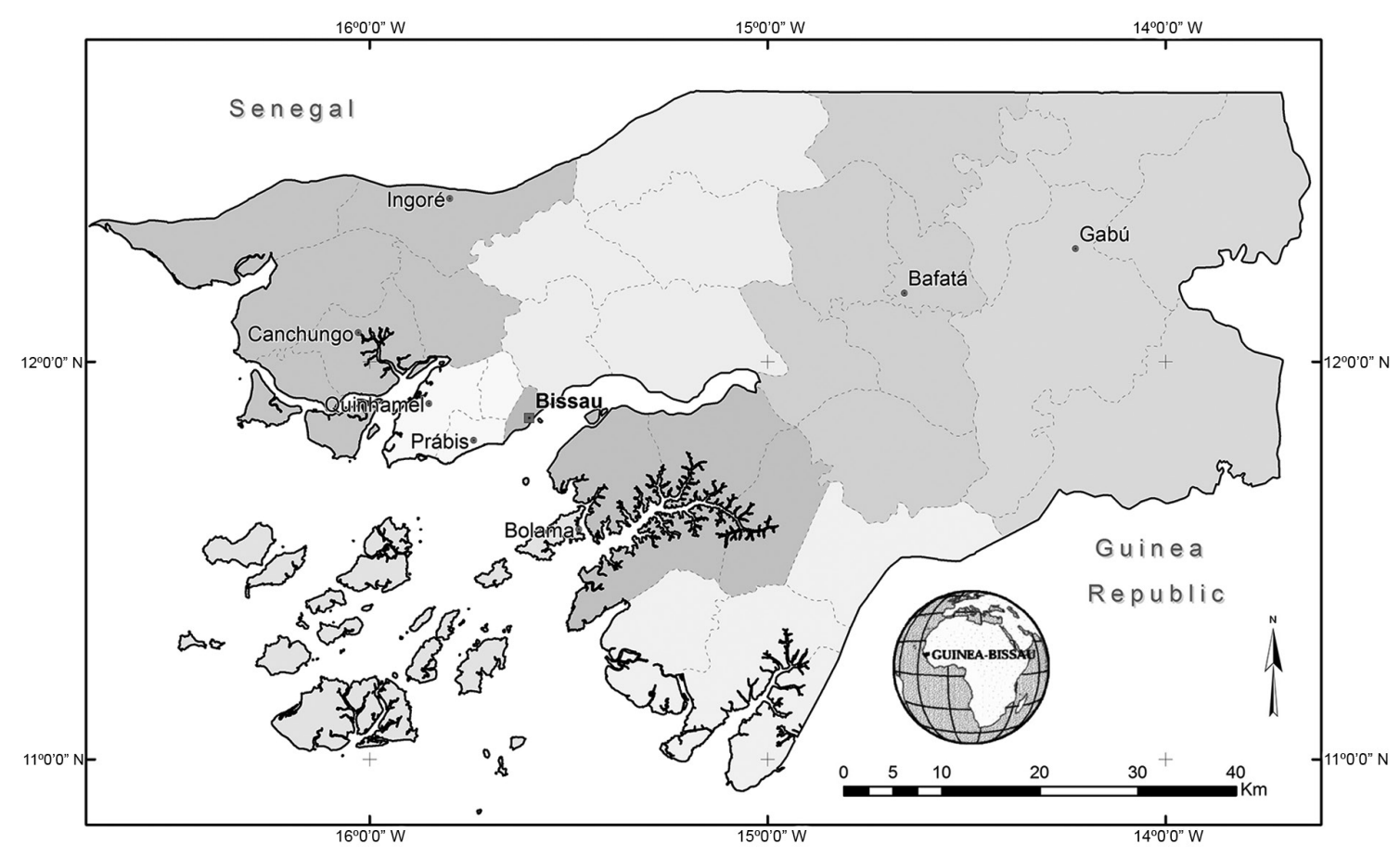

Figure 1 - Guinea-Bissau map showing the locations referred to in the text.

in Guinea-Bissau is suitable for cashew cultivation, although a tuned ecological and land capability zoning remains to be established in the country.

There is some controversy about the existence of several cultivated varieties of $A$. occidentale. Many citations on cashew cultivated varieties are found in several countries but, as happens in Brazil, India and Guinea-Bissau such biotypes are identified solely on the basis of the form, size and colour of the false fruit as well as nut size. A list of these so called cultural varieties can be identified in the descriptions presented, among other authors, by Papademetriou and Herath (1996).

\section{Cashew tree products and uses}

Cashew was originally used in Africa in afforestation schemes or as a fire protection barrier around forest demarcations (Goujon et al., 1973). Currently, it is recognized as one of the most important tropical crops and referred to as the "poor man's crop, rich man's food", and is grown for its nuts (Jaffee, 1994). The kernels, which have a high nutritional and commercial value, are used for human consumption after decortication. The cashew nut processing industry is an important economic activity in several countries such as India, Brazil and Vietnam and has also recently gained expression in the Ivory Coast and Nigeria. The main steps involved in cashew processing are as follows: drying of freshly harvested raw seed for storage, soaking of the seed, steam cooking, hot oil roasting or dry roasting, shelling, separation, kernel drying, peeling and packaging.
The cashew nut shell liquid (CNSL) or cashew balm is a highly corrosive oil produced in the large cells of the pericarp, with numerous industrial and medical applications (Orwa et al., 2009). CNSL is therefore a valuable product, but is ultimately burnt off during the roasting process, even by large processors such as India. A number of other products and uses are reported for the cashew tree. The edible false fruit or cashew apple can be eaten fresh or mixed in fruit salads and is important in several countries. Drinks are also prepared from the juice, as well as sweets and jams (Behrens, 1996). The high sugar content of cashew juice permits the making of a fermented beverage, cashew wine, which can be distilled to make spirits. Although apple juices, jams and spirits have a long tradition of consumption, marketing cashew apple by-products is not internationally extensive. The wood of $A$. occidentale is fairly hard with a density of about $500 \mathrm{~kg} \mathrm{~m}^{-3}$ (Orwa et al., 2009), being used as timber, firewood and in the production of charcoal. Several other products can be obtained from the plant such as fibers, tannin, gum or resin and the species also has numerous medicinal applications.

Given its high tolerance to external conditions and moderate demand on soil characteristics, this crop has been planted in poor soils to prevent erosion and to recover the fertility of land degraded by annual crops. The tree is also suitable for use in agroforestry systems and can be intercropped with both annual and perennial herbs as well as trees and shrubs (Behrens, 1996; Orwa et al., 2009). 
The present study aims at providing an account of the process of cashew tree expansion in Guinea-Bissau, reviewing the current situation, highlighting the importance acquired by the cashew sector in the country, its socio-economic importance and weaknesses, and discussing its future prospects.

\section{The cashew tree in Guinea-Bissau}

\section{From colonial times to the present boom}

The cashew tree was introduced into Guinea-Bissau by the Portuguese in the XIXth century and during the early XXth century and was mainly used in local farmers' home gardens. Cashew cultivation had a first organized impulse under the instigation of Governor Sarmento Rodrigues (1945-1949), who promoted its expansion. By the mid-1950s, nut production was estimated to reach 300$400 \mathrm{t}$ per year. The potential value of the cashew tree, its hardiness and the possibility for use in intercropping or as a kind of cover for long fallow periods in order to recover soil fertility, has been suggested as a priority for research and experimentation. As a consequence, the Overseas Agronomic Research Mission (MEAU) designed the Cashew Development Plan in Portuguese Guinea. The plan was developed under an integrated value chain perspective, considered necessary for the development of the territory and its people. Thus, to fulfill its objectives, during the 1960s MEAU set up a multi-disciplinary six year research project. Given the tree's rusticity, MEAU promoted cashew cultivation in soils depleted by other crops such as maize, upland rice or groundnuts, as well as by fire (Sardinha and Horta, 1966).

Some research was conducted on the possibility of establishing this crop in the colony, taking into account former experience in Mozambique, a major cashew producer at that time. As part of its extension work, nurseries were established in Bafatá, Bissau, Bolama Island, Canchungo and Prábis (Figures 1 and 2), and several tens of hectares of orchards were planted. As an incentive to expand the crop, a taungya system of contract plantation with interested farmers was designed awarding a money prize for each cashew tree planted (Sardinha and Horta, 1966). By the mid-1960s, cashew nut exports had reached 125 tons and continued to increase during the 1970s (Table 1).

At the end of 1974, marking the end of the colonial era, several hundred hectares of cashew orchards had been planted, but no industrial processing of cashew nuts or apples was carried out. The amount of raw cashew available was still not enough to feed a decortication unit with a capacity considered economically viable at the time. Thus, the impetus for development of cashew gained during the 1960-74 period, was dampened in post-independence. However, some non-governmental organizations and cooperation agencies developed a relevant action using cashew in the context of forest interventions. The use of cashew trees as a cash crop, in forest protection schemes or as a way to recover soil

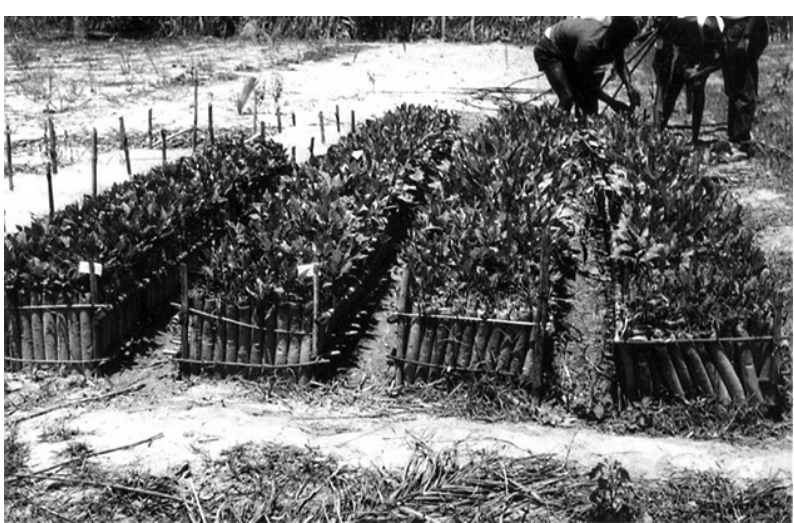

Figure 2 - Cashew nursery settled in the 1960's decade at Granja do Possubé, Bissau.

Table 1 - Trends in the export of cashew nuts 1966-1974

\begin{tabular}{lcc}
\hline Year & Quantity Exported (tons) & Annual Exportation Increase (\%) \\
\hline 1966 & 150 & - \\
1967 & 665 & 343 \\
1968 & 549 & -17 \\
1969 & - & - \\
1970 & 1191 & 58 \\
1971 & 666 & -44 \\
1972 & 1908 & 186 \\
1973 & - & - \\
1974 & 1273 & -17 \\
\hline
\end{tabular}

Source: data from Ministry of Commerce of Guinea-Bissau.

fertility in fallows was stressed. Cashew was considered an important species to be used to restrain deforestation, because of its acceptability by the peasants. A semi-manual decortication unit with a capacity of $250 \mathrm{t}$ per year and a bottling line for cashew apple juice and jams were built on Bolama Island in the late 1970's with Dutch co-operation. Although this plant has proved to be economically unsustainable, its implementation was a strong boost to cashew cultivation.

By the mid-1980s, two factors gave new impetus to the intensity of planting and trading in the domestic market. The first was a non-organized race for the occupation of land by villagers, as a result of a significant increase in land grants to commercial farmers or "ponteiros" by government authorities. Since 1984, government policy aiming to increase agricultural production initiated large concession grants and, as of 1987, land distribution increased. It was estimated to represent around 300,000 ha out of an estimated agricultural area of $1,100,000$ ha and 1,400,000 ha of silvo-pastoral land. These lands, contrary to what happens with traditional farmers, were demarcated and registered in the Land Registration Services of the Ministry of Public Works.

The gaps in the land property law, which overlooked customary rules that grant property rights to those who planted permanent crops, meant that traditional farmers tried to secure land to ensure their access 
to it. Cashew, due to its hardiness and quick growth, was an obvious choice. The second driving force was the authorities' initiative to curtail cashew smuggling to Senegal, due to increased internal consumption and the revival of the cashew decortication factory in the Sokone province of that country. An informal barter trading practice was thus put in place, wherein cashew was exchanged for rice at a ratio of one to two, which evolved due to the relative change of the quotations of the two commodities to one to one. More recently, data from a country report for 2013 report a deterioration in the terms of trade, $1 \mathrm{~kg}$ of rice being exchanged for up to $3 \mathrm{~kg}$ of cashew (Cont and Porto, 2014).

Another factor which can help to understand the continuous cashew expansion and consequent decrease in production of staple crops. It is the comparative advantage of cashew in terms of the differential days invested by cultural cycle and added value of the agricultural work invested per day. Since the traditional farmers' strategy was to optimize work invested in agriculture, we can see a strong drive to shift from traditional agricultural practices to cashew cultivation (Table 2).

The area cultivated with cashew and cashew nut production has increased continuously in the last decades. The data on cashew nut production and cultivated area for the country in the period 1978-2012, obtained from FAO statistics, are presented in Table 3. For 2012, there is an estimated area under cashew cultivation of 223,000 ha with an annual production of 130,000 tons of raw cashew nuts. The annual growth rates estimated for the period 1978-2012 were $8 \%$ in area under cultivation and $12 \%$ in production $(\mathrm{FAO}, 2015)$.

Because plantation sizes are often unknown and variable, and theft is common, it is nearly impossible to gather reliable yield data, either on a per hectare or a per tree basis. The most recent estimates, available from unpublished reports, point to $500-600 \mathrm{~kg} \mathrm{ha}^{-1}$ or up to 680 $\mathrm{kg} \mathrm{ha}^{-1}$ of cashew nuts in small farmer orchards. Nevertheless, the farms where more accurate data is available have reported yields of only $378 \mathrm{~kg} \mathrm{ha}^{-1}$ of nuts, significantly below the yield claimed for the country. The figures reported for other African countries range in most cases from 400 to $500 \mathrm{~kg} \mathrm{ha}^{-1}$ (Behrens, 1996).

Table 2 - Comparative advantage of the cashew crop in relation to main crops in Guinea-Bissau. (CFA franc is the local currency, the West African CFA franc - Source: unpublished report)

\begin{tabular}{lccc}
\hline $\begin{array}{l}\text { Agriculture } \\
\text { option }\end{array}$ & $\begin{array}{c}\text { Days } \\
\text { spent }\end{array}$ & $\begin{array}{c}\text { Added value per } \\
\text { day (CFA franc) }\end{array}$ & $\begin{array}{c}\text { Differential advantage as } \\
\text { compared with cashew (CFA franc) }\end{array}$ \\
\hline Paddy rice & 312 & 232 & $-2,478$ \\
Pluvial rice & 109 & 177 & $-2,533$ \\
Maize & 70 & 1657 & $-1,053$ \\
Sorghum & 94 & 870 & $-1,840$ \\
Millet & 114 & 618 & $-2,092$ \\
Peanuts & 78 & 660 & $-2,050$ \\
Cotton & 115 & 987 & $-1,723$ \\
Cashew & 118 & 2710 & 0 \\
\hline
\end{tabular}

Presently, cashew is by far the most important cash crop in Guinea-Bissau, representing $90 \%$ of the country's exports and the main source of income in rural areas, involving to a varying extent about $80 \%$ of the population (Cont and Porto, 2014; Doré et al., 2006). In fact, in recent decades the progressive expansion of cashew cultivation has led to important changes both in the countryside landscape and in the traditional way of life in rural communities, due to the conversion of vast areas of slash-and-burn shifting agriculture to orchards dedicated to a single cash crop.

\section{Cropping systems and cultivated varieties}

Two main types of cropping systems co-exist in Guinea-Bissau: the peasant and the commercial system, locally known as "ponteiro". The vast majority of cashew orchards are owned by small farmers in villages all over the country. The average smallholder plantation is thought to cover 2-3 hectares, though farmers often have no idea of the size of their planted area.

The process of cashew expansion usually starts in the land closest to the center of villages and expansion follows a centrifugal trend. A piece of fallow land or semi-natural woodland or savanna woodland is prepared by cutting down the woody vegetation, which is burned by the end of the dry season. In the most frequently used system, cashew is intercropped in the first two or three years with food crops (e.g.: rainfed rice, millet, sorghum, maize or groundnuts). Every year a new piece of land can be prepared and sown with cashew and food crops. Cashew trees are sometimes also planted as live fences, despite the fact that their spreading habit makes them unsuitable for close spacing.

Table 3 - Area cultivated and nut production in Guinea-Bissau for the period 1978-2012.

\begin{tabular}{cccccc}
\hline Year & Area & Production & Year & Area & Production \\
\hline & ha & tons & & ha & tons \\
1978 & 14000 & 3000 & 1996 & 105000 & 38580 \\
1979 & 14000 & 3000 & 1997 & 150000 & 57887 \\
1980 & 16000 & 3500 & 1998 & 160000 & 64000 \\
1981 & 22000 & 5000 & 1999 & 190000 & 73156 \\
1982 & 22000 & 5000 & 2000 & 210000 & 72725 \\
1983 & 22000 & 5000 & 2001 & 192285 & 85000 \\
1984 & 45000 & 12000 & 2002 & 212000 & 86000 \\
1985 & 47000 & 13000 & 2003 & 213502 & 84586 \\
1986 & 50000 & 15000 & 2004 & 225063 & 96649 \\
1987 & 55000 & 18000 & 2005 & 213000 & 89000 \\
1988 & 55000 & 18000 & 2006 & 212000 & 95000 \\
1989 & 80000 & 30000 & 2007 & 215593 & 98000 \\
1990 & 80000 & 30000 & 2008 & 215000 & 99000 \\
1991 & 64580 & 20824 & 2009 & 218000 & 99500 \\
1992 & 80000 & 30000 & 2010 & 218002 & 108029 \\
1993 & 75000 & 32775 & 2011 & 222517 & 128684 \\
1994 & 80000 & 24793 & 2012 & 223000 & 130000 \\
1995 & 90000 & 29007 & & & \\
\hline
\end{tabular}

Source: FAOSTAT data. 
Plant spacing is traditionally very close (e.g.: 3-5 $\mathrm{m})$, with roughly defined or even non-existent rows. However, in recent years this trend has begun to change, with greater plant spacing and the use of well-defined rows in the younger cashew orchards. Within the lines the trees are often paired because two seeds are sown per hole with the idea that at least one may survive. Farmers who sow close together often do so following the advice to sow a large number of trees and thin them later, which is a good proposition for rapid establishment of a crop, minimizing costs of weed clearing and avoiding severe development of termite colonies. Unfortunately, many farmers never get around to thinning the trees.

At the level of the small farmer there is no varietal selection and no care is taken in the establishment of orchards. There is also no support dispensed by the very weak structures of agricultural research and extension in the country. These orchards, owned and explored at the family level, are small, rarely exceeding a few hectares and growing with virtually no agro-chemical inputs.

To tackle some of the problems mentioned, in the 1990 decade the Trade and Investment Promotion Project (TIPS) included an extension component that promoted cashew planting seminars around the country, nursery establishment and post-harvest technologies. However, at the end of the project, no ministry took over the continuation and consolidation of the objectives. Therefore, only a minority of farmers had incorporated the knowledge made available.

At the "ponteiro" or commercial system level, a number of plantations are distributed throughout the country, with great heterogeneity in terms of size and care dispensed to the orchards. The orchards owned by small "ponteiros" are established using a method similar to that of the traditional farmers, with no care for the choice of seeds and close tree spacing. Conversely, in a few agro-industrial farms whose extension surpasses 1000 hectares in some cases, care has been taken in the selection of parent material and in adequate tree spacing. Nevertheless, in both peasant and commercial systems no agro-chemical inputs were used in the cashew orchards. Thus, the Guinean cashew nuts are organic and can fetch a higher price if suitably processed and marketed, and comply with stringent hygiene standards as demanded by international markets. However, this is yet to be fulfilled.

From the two main types of cashew trees, based on tree height, presently recognized (e.g.: Araujo, 2013), only large trees are cultivated in the country and no dwarf cashew trees are known. However, two main types of $A$. occidentale are recognized in the country, one with yellow and one with red false fruits. Nevertheless, propagation is effected by seeds of cross pollinated plants, so the question of cultivated material is somewhat spurious. In Guinea-Bissau, red cashew is known as "caju-di-terra" (local cashew). It presents small nuts, weighing 3-4 g each and an apple with sweet juice, much used to make juice and fermented beverages. The yellow cashew, known as caju-di-Moçambique (Mozam- bique cashew) produces larger nuts, weighing 6-8 g each, which is still classified under the commercial trade class stratification as small nuts. The yellow apple is larger, but is more fibrous and the juice is less appreciated.

Recognizing that cashew grade quality is of paramount importance for the export market and for the industry, an attempt was made to improve the production material in the second half of the 1980s through two EU financed projects (Bessa and Sardinha, 1993). A progeny test and introduction of new genotype material was conducted. In representative production areas of the country, 45 locally selected genotypes and 6 new imported genotypes were duly planted but this line of research was abandoned after the project ended. Some research on orchard establishment, maintenance and vegetative propagation techniques including tissue culture was also conducted. However, given the paucity of resources for agricultural extension, it seems that the results were not subsequently applied in the field.

\section{Cashew tree and land ownership}

In Guinea-Bissau the land is formally considered state-owned but, as in most of West Africa, consuetudinary land tenure practices are linked to the planting of perennial plants, in particular fruit trees (Fenske, 2011). In times of increasing population density, and when the sale of land is becoming a common practice, cashew orchards can act as land tenure insurance (Temudo and Abrantes, 2012). In this respect, the cashew nut tree possesses several advantages: it is a rapid growing tree which does not require much care or manpower to establish and maintain and, above all, produces a non-perishable fruit with an assured market. On the other hand, cashew works like insurance for the elderly, in times of exodus of young males to the towns, because it requires little manpower that can be largely provided by women and children (Lundy, 2012). The role of cashew trees in the marking of land tenure can thus explain, to a certain extent, the success of the crop and is a matter that requires further study.

\section{Trade, exportation and local processing of cashew}

The outflow of annual production of cashew nuts occurs during the so-called "cashew campaign", which runs approximately from March-April to August. During this period, small free-lance buyers and officers of medium sized companies travel the country acquiring cashew nuts or exchanging them for rice.

From 2004 onwards, the cashew nut market became relatively liberalized and less dependent on rice bartering and more on a cash basis than previously. In approximate terms, the overall marketing chain from farm to port is quite short. There are up-country buyers acting on behalf of urban buyers; raw cashew nuts are delivered to town warehouses where they may be further dried, bagged and consolidated in loads, or sent directly to exporters in Bissau. Exporters may or may not re-bag the cashew nuts and then sell them to inter- 
national dealers or processors for shipment to India. Participation in this chain of commercialization is licensed and each of the agents in the chain has to pay a fee to the Ministry of Commerce and the Chamber of Commerce, Industry and Agriculture (CCIA). As of 2004 there were about 300 registered buying agents and 40 exporters.

Fleeing from this general scheme, rural farmers maintain the custom of receiving a loan on rice on account of cashew nuts to produce the next season, often at an exchange ratio unfavorable for them. In years of low cashew nut production, this practice can have serious consequences for small farmers, specifically at the food security level.

The absence of a legislative and regulatory framework to structure the cashew market, a commodity that commands such importance to the country's economy is surprising, and is a situation which should be remedied so that it can function with integrity and transparency of price formation and transactions. Without this market structuring, for which there are already positive examples in Africa, it is difficult to attain a fair partition of benefits for the majority of farmers.

There is always disagreement as to exactly how much is produced. Statistical information hardly accounts for what remains in the warehouses because of missing the export season, or what is internally consumed or smuggled. Recent estimates report an annual production of 200,000 tons of raw cashew nuts, making Guinea-Bissau the fifth largest producer in the world. Nevertheless, the exports greatly fluctuate from one year to another: 120 to 170 thousand tons in the period 2009-2011. On the other hand, the political instability in the country, as well as the lack of infrastructures and uncertainty in taxes, do not favor a proper functioning of the sector. Fluctuations in the estimates are mainly due to the rather precarious information concerning area, and to the assumptions made about productivity and internal consumption.

Most of the cashew nut produced in Guinea-Bissau is exported to India to be processed there, and only a small fraction is processed locally. A recent report estimated the processing capacity installed in the country at about 15 thousand tons of raw cashew nuts per year $(9$ $\%$ of the estimated production of the country) and about 25 thousand tons of raw cashew nuts per year as the projected processing capacity for the near future $(15 \%$ of the estimated production). However, these figures seem to be largely overestimated: for instance, in 2012 less than 500 tons of processed cashew nuts were exported. It is difficult for even the largest processors in the country to comply with the demands of the international cashew nut market in terms of quantity and quality. Only in recent years did co-operation between processors become a common practice for overcoming that constraint. On the other hand, there have been a number of projects to develop small scale processing but it is difficult to obtain information on exactly how much is being processed.

Besides the number of factories mentioned, it is important to note that, in almost all villages, there is informal manual decortication carried out by women. First, the nuts are roasted until the cashew liquid is extracted and burns away and the shell becomes brittle. Then the shell is broken with a wood mallet and the membrane surrounding the kernel is removed by hand. Peddlers sell larger quantities of kernels at their homes, near ferry landings and other public places. Though a common reference of internal consumption of this home processing is $5 \%$, no studies or data are available on the significance of this market outlet or on the quantity of cashew sold as decorticated kernels. There is also a generalized perception that this home-made decortication does not have external marketing value.

\section{Other cashew products and services used in Guinea- Bissau}

In addition to being grown as a cash crop for nut production, cashew has a number of other uses in the country. Based on nut production and the assessed ratio of cashew apple/cashew nuts (1:9), unpublished data evaluate the cashew apple annually produced to be around 1,500,000 $t$, though these figures may be largely overestimated, and this can be a valuable raw material with several applications. However, a large amount of false fruit is not collected in practice, as is the case in plantations where workers are hired to gather nuts. The juice storage constraints are another limiting factor hampering the full use of apples. As such, in the interior villages most of the false fruit and its derivatives are consumed rather than sold. The cashew apple, although potentially important, has a disproportionately low contribution to farmers' income. Although outside the market circuits, it is important not to forget the significant contribution that the cashew apple brings to the food balance of the peasant population in the fully dry season period as rice stocks start to run low.

A plant producing cashew apple juice was established on Bolama Island in the late 1970s but is no longer in service. Nevertheless, some artisanal production of cashew apple juice, "cajuina", is made in Bissau, Canchungo, Ingoré and Quinhamel. Given the climatic conditions of the country, cashew apple juice begins to ferment only hours after harvest. Therefore, the use of the cashew apple is conditioned by local religious beliefs. Since the ethnic Muslim groups do not use or sell alcohol, the cashew apple produced by Muslim farmers, dominant in the inner parts of the country, remains largely unused or otherwise used as fodder only. In the non-Muslim ethnic groups the juice is fermented and drunk as wine or distilled to make spirit. During the fruiting season the commerce of cashew wine and spirit flourishes, particularly in Bissau and its surroundings. In some cases, the recent abundance of cashew wine and spirit may be changing the traditional relationship with alcohol. Spirit in particular, traditionally used in ceremonies and on special occasions, is now much more accessible with consequences as yet unknown (Lundy, 2012). 
Guinean women and children are the primary harvesters of cashew and the primary marketers of cashew juice and wine. Although requiring further analysis, women who discussed the subject said the revenue from the cashew harvest represented more than half of their annual earnings (Lea et al., 1990). The economic importance that women attach to this activity justifies the annual internal migration of women to the countryside during the harvest season. The wood of the cashew tree can serve many purposes, but is not frequently used in Guinea-Bissau, as most of the orchards are in full production and pruning is not carried out. Nevertheless, as the cashew orchards expand and age, the trees begin to die and their wood is used mainly as fuel. Several parts of the plant also have medicinal uses in the country, namely the leaves and the bark of the trunk (Catarino et al., 2013).

\section{The risks and challenges of cashew culture in Guinea-Bissau}

In recent decades the cashew sector has acquired an enormous importance in Guinea-Bissau's economy, both in terms of national budget and of the livelihood of rural populations. This high dependency - cashew nuts make up about 90 percent of Guinea-Bissau's sum exports (Boubacar-Sid et al., 2007) - involves risks to the national economy, as cautioned by several authors (e.g.: Doré et al., 2006). The development of extensive monospecific plantations like cashew in Guinea-Bissau harbors risks, such as increased vulnerability to weather hazards, as well as to the potential for emergence of pests and diseases, which either adapt to local conditions or are accidentally imported. On the other hand, a rise in world production or a drop in demand, may force down the price paid for Guinean raw cashew nuts and the same can occur due to an increase in output from more competitive suppliers. Each one of these shortterm scenarios may occur such as happened in recent years: in 2011 and 2012, $1 \mathrm{~kg}$ of cashew was purchased for between 250-350 CFA (African Financial Community) francs as opposed to 100-210 CFA francs in 2013. Each of these scenarios is likely to occur in the medium to long term, and can result in dramatic losses of export earnings that would impact the living standards of Guineans in both urban and rural areas. Moreover, at present practically all cashew nut is exported raw to the Indian market, which implies that the market for BissauGuinean nuts is more restricted than might be assumed by references to the international market.

In addition to these macroeconomic impacts we cannot ignore the critical consequences accruing to food security in the country. Rice production is declining in Guinea-Bissau, partly due to the increase in cashew cultivation, and as a result, rice imports have increased. A deterioration in the terms of international trade or other factors that hamper raw nut sales, can negatively impact the availability of rice and the food security of populations.

\section{Pests and diseases}

A. occidentale is susceptible to over 60 known insect pests during different stages of its growth (Araújo, 2013; Orwa et al., 2009). The species is also attacked by several diseases, some of which have high potential for damage (e.g.: Freire et al., 2002). However, information published on enemies of cashew in Guinea-Bissau is scarce. Vasconcelos et al. (2014) reported the occurrence of several insects, of which three seem to be particularly damaging: the stem borer Apate terebrans Pallas (Coleoptera, Bostrichidae), is a polyphagous wood-boring beetle which infests planted as well as naturally regenerating forests. Both larvae and adults tunnel into living trees inflicting significant damage and even the death of trees. The trunk and root borer, Plocaederus ferrugineus Linnaeus (Coleoptera: Cerambycidae), is able to kill trees within weeks of infestation and is an increasing threat to cashew in the country. The stem girdler, Analeptes trifasciata Fabricius (Coleoptera: Cerambycidae) is also a matter of concern as this species is increasingly prevalent in the southern part of the country. All three species have been described as serious pests, for instance, in Nigeria (Asogwa et al., 2009, 2011; Hammed et al., 2008).

Anthracnose is considered the most significant disease of cashew in several countries (e.g.: Araújo, 2013; Freire et al., 2002), and appears to be spreading in Guinea-Bissau. The causal agent is commonly assigned to the fungal species Colletotrichum gloeosporioides Penz. \& Sacc., a group of polyphagous pathogens common in tropical fruit plants. The selection of resistant genotypes to anthracnose in the country were already subject to study but the results and consequent selection and multiplication of resistant clones were not applied in the field. Gummosis is an exudative disease described in 1991 in Brazilian cashew plantations. The fungus Lasiodiplodia theobromae (Pat.) Griffon \& Maubl. was found to be the causal agent (Freire et al., 2002). This pathogen is also responsible for the twig and floral shoot die-back, important diseases, for instance, in Nigerian orchards (Hammed et al., 2008). Gum exudation is the most visible symptom of gummosis but lesions may reach deep woody tissues, completely blocking the sap flow and leading to death of the trees (Freire et al., 2002). In the Guinean orchards, gummosis seems to be expanding and is beginning to kill trees .

Given the extent of the area occupied by this monoculture, the inadequate functioning of agricultural extension in the country and the low level of education and organization of producers, the spread of pests and diseases in cashew may become an additional serious problem in the short or medium term in Guinea-Bissau.

\section{Final remarks}

The cashew tree is well adapted to most of the soils and climate conditions of Guinea-Bissau (Goujon et al., 1973) and has become the preference of the Guinean 
farmers. It is less vulnerable to inter-annual rain variations and requires less manpower than alternative crops, produces fruits which are easy to collect and store and, until recently, without major marketing problems. Moreover, in a country where land ownership is still an open question, cashew establishes a bond with the land and a means of securing it. Not surprisingly, the area cultivated with cashew has dramatically increased in a few decades and is likely to continue to expand in the near future. The cashew sector is presently the most important economic activity in the country, but the strong dependence on this crop involves some potentially dangerous risks for the country and its inhabitants, particularly local farmers.

These risks are accentuated by the political instability in the country, the low value added along the value chain, the fragility of research, development and extension that is being carried out, and the legal framework, which must be improved in order to convert an activity which for local farmers is little more than a collecting activity, into a real business. So, achieving an appropriate level of diversification in agricultural production and increased productivity through appropriate technology, better management practices and better germplasm, as well as accrued added value of cashew production is needed to minimize risks for farmers and to achieve long-term stability. It is, therefore, important to reach a balance between food security and diversity of cash crops. This is especially so for tree crops, which have a much longer time frame to maturity than annual crops.

The changes induced by the cashew boom at the social and environmental levels still need to be deeply analyzed and understood. Cashew is a small tree cultivated in monospecific orchards with a closed, monolayered vegetation structure. Scattered remnant trees are not always present and plant diversity in cashew orchards is lower than in the former forest fallows. As the area of cashew orchards increases, the land devoted to fallow or other crops (e.g.: upland rice, peanuts, sorghum) diminishes and the natural vegetation becomes increasingly fragmented, with consequences not yet understood in relation to biodiversity. Nevertheless, it seems that cashew orchards can conserve the potential for forest recovery as documented by Sousa et al. (2015).

Co-utilization without conflict by people and chimpanzees of the cashew nuts and false fruits, respectively, was also reported in the area of Cantanhez National Park, Tombali region (Hockings and Sousa, 2012). On the other hand, the demand on services provided by the natural ecosystems (e.g.: bush-meat, fuel wood, wild fruits and roots, and medicinal plants) may be increasing, leading to greater pressure over the remnant patches of natural vegetation. Fire is a common feature in the savannahs and woodlands of Guinea-Bissau and a further issue deserving attention is the relationship between fire and cashew orchards. Since cashew flowering and fruit bearing are significantly affected by fires, a decrease in the number and intensity of bushfires in areas of intensive cashew cultivation is likely (Temudo and Abrantes, 2014).

It is the authors' belief that if Guinea-Bissau is going to maintain its international raw cashew earnings and penetrate the cashew kernel market successfully, it will have to adopt an active position in three main sectors:

1) Improvement and protection of raw nut production, that will include: i) germplasm research moving ahead local selection to broaden the genetic base of Guinean production; ii) use of vegetative propagation (e.g.: grafting, canopy replacement) to reproduce selected parent material or to introduce improved high yielding and/ or disease resistant clones, requiring suitable quarantine facilities to protect existing production; iii) efforts to strengthen the crop protection service; iv) agronomic intervention, directed to improve plant establishment, orchard management and opportunity analysis for intercropping as a way to increase food security.

2) Capture the added value available at the supply chain thereby achieving better nut compliance with international standards and expansion of the processing capacity to realize economies of scale so that the international market could rely on a minimum of quantities and regularity of supply. The current policy of fragmented decortication must be thoroughly analyzed from this point of view.

3) Intervention in the kernel and cashew market. GuineaBissau has no visibility in the kernel market, and potential buyers can be expected to hesitate about kernels from an unknown source. Developing a reputation as a supplier requires stringent quality control, certification to recognized standards of decortication practices and development of a brand in which buyers will have confidence in terms of quality and regular supplies. Achieving a market reputation is difficult for a single or even a number of small factories scattered throughout the country. Larger volume is needed which is difficult for small factories. Quality control should not be left to individual and semi-artisanal processors nor to exporters. An inspection agency is needed with official power to issue quality label certificates, including those for organic production. On the other hand, diversification in cash and food crops is an important instrument for reducing the dependency of the economy on cashew production and the exporting of raw nuts.

\section{Acknowledgements}

This work was funded by Portuguese National Funds through FCT - the Foundation for Science and Technology under the project PTDC/AFR/117785/2010.

\section{References}

Araujo, J.P.P. 2013. Agribusiness Cashew: Practices and Innovations = Agronegócio Caju: Práticas e Inovações. Embrapa, Brasília, DF, Brazil (in Portuguese). 
Asogwa, E.U.; Anikwe, J.C.; Ndubuaku, T.C.N.; Okelana, F.A. 2009. Distribution and damage characteristics of an emerging insect pest of cashew, Plocaederus ferrugineus L. (Coleoptera: Cerambycidae) in Nigeria: a preliminary report. African Journal of Biotechnology 8: 53-58.

Asogwa, E.U.; Ndubuaku, T.C.N.; Hassan, A.T. 2011. Distribution and damage characteristics of Analeptes trifasciata Fabricius 1775 (Coleoptera: Cerambycidae) on cashew (Anacardium occidentale Linnaeus 1753) in Nigeria. Agriculture and Biology Journal of North America 2: 421-443.

Behrens, R. 1996. Cashew as an Agroforestry Crop: Prospects and Potentials. Margraf Verlag, Weikersheim, Germany.

Bessa, A.M.S.; Sardinha, R.M.A. 1993. The improvement of cashew tree in Guinea-Bissau = O melhoramento do cajueiro na Guiné-Bissau. Comunicações IICT 13: 141-151 (in Portuguese).

Boubacar-Sid, B.; Creppy, E.G.E.; Gracitua-Mario, E.; Wodon, Q. 2007. Conflict, livelihoods, and poverty in Guinea-Bissau. World Bank, Washington, DC, USA. (Policy Research Working Paper, 88). Available at: http://siteresources.worldbank.org/ EXTDEVDIALOGUE/ Resources/Conflicts_Livelihoods_ GB.pdf [Accessed Jan 5, 2015].

Catarino, L.; Indjai, B.; Mourão, D. 2013. Agents and plants used in traditional medicine in the Orango Island (Guinea-Bissau). Scripta Botanica Belgica 50: 381-390.

Catarino, L.; Martins, E.S.; Basto, M.F.P.; Diniz, M.A. 2008. An annotated checklist of the vascular flora of Guinea-Bissau (West Africa). Blumea 53: 1-222.

Cont, W.; Porto, G. 2014. Measuring the Impact of Change in the Price of Cashew Received by Exporters on Farm Gate Prices and Poverty in Guinea-Bissau. World Bank, Washington, DC, USA. (Policy Research Working Paper, 7036). Available at: http://www-wds.worldbank.org/external/default/ WDSContentServer/IW3P/IB/2014/09/16/000158349_2014091 6111204/Rendered/PDF/WPS7036.pdf [Accessed Mar 5, 2015].

Doré, O.; Ocampos, L.; Sáenz, M.; Veyrune, R. 2006. GuineaBissau: Selected Issues and Statistical Appendix. International Monetary Fund, Washington, DC, USA. Available at: http:// www.imfbookstore.org [Accessed Mar 20, 2014].

Fenske, J. 2011. Land tenure and investment incentives: evidence from West Africa. Journal of Development Economics 95: 137-156.

Food and Agriculture Organization [FAO]. 2015. FAOSTAT. FAO, Rome, Italy. http://faostat3.fao.org/browse/Q/QC/E [Accessed Jan 5, 2015].

Food and Agriculture Organization [FAO]. 2014. Forests and forestry in small island developing states: forest resources. FAO, Rome, Italy. Available at: http://www.fao.org/forestry/ sids/4142/en/ [Accessed Mar 20, 2014].

Freire, F.C.O.; Cardoso, J.E.; Santos, A.A.; Viana, F.M.P. 2002. Diseases of cashew nut plants (Anacardium occidentale L.) in Brazil. Crop Protection 21: 489-494.

Goujon, P.; Lefebvre, A.; Leturcq, Ph.; Marcellesi, A.P.; Praloran, J.P. 1973. Studies on cashew tree $=$ Études sur L'anacardier. Bois et Forêt des Tropiques 151: 27-53 (in French).
Hammed, L.A.; Anikwe, J.C.; Adedeji, A.R. 2008. Cashew nuts and production development in Nigeria. American-Eurasian Journal of Scientific Research 3: 54-61.

Hockings, K.J.; Sousa, C. 2012. Differential utilization of cashew, a low-conflict crop by sympatric humans and chimpanzees. Oryx 46: 375-381.

Jaffee, S. 1994. Private Sector Response to Market Liberalization: The Experience of Tanzania. World Bank, Washington, DC, USA. (Policy Research Working Paper, 1277). Available at: http://www-wds.worldbank.org/external/default/ WDSContentServer/IW3P/IB/1994/03/01/000009265_39610060 31525/Rendered/PDF/multi_page.pdf [Accessed Mar 5, 2015].

Johnson, D.V. 1973. The botany, origin and spread of the cashew Anacardium occidentale L. Journal of Plantation Crops 1: 1-7.

Lea, J.D.; Hugo, C.; Cardoso, C. 1990. A Review of the Cashew Sub-Sector in Guinea-Bissau. Food and Feed Grains Institute, Manhattan, KS, USA. (Report, 119). Available at: http://pdf. usaid.gov/pdf_docs/pnabg194.pdf [Accessed Mar 20, 2014].

Lundy, B.D. 2012. Playing the market: how cashew "Comodityscape" is redefining Guinea-Bissau's countryside. Culture, Agriculture, Food and Environment 34: 33-52.

Orwa, C.; Mutua, A.; Kindt, R.; Jamnadass, R.; Simons, A. 2009. Agroforestry database: a tree reference and selection guide version 4.0. Available at: http://www.worldagroforestry.org/ treedb2/AFTPDFS/Anacardium_occidentale.pdf [Accessed Mar 20, 2014].

Papademetriou, M.K.; Herath, E.M. 1996. Integrated production practices of cashew in Asia. Food and Agriculture Organization, Rome, Italy. Available at: http://www.fao.org/docrep/005/ ac451e/ac451e00.htm\#Contents [Accessed Mar 20, 2014].

Sardinha, R.M.A.; Horta, C.A.P. 1966. Prospects for Agriculture, Forestry and Livestock in Guinea - Some promotion Actions = Perspetivas da Agricultura, Silvicultura e Pecuária na Guiné - Algumas Acções de Fomento. Boletim Cultural da Guiné Portuguesa 21: 241-306 (in Portuguese).

Sousa, J.; Luz, A.L.; Sousa, F.N.; Cassama, M.; Dabo, A.; Dafa, F.; Abrantes, M.B. 2015. Cashew orchards conserve the potential for forest recovery. Agroecology and Sustainable Food Systems 39: 134-154.

Temudo, M.P.; Abrantes, M. 2012. Changing policies, shifting livelihoods: the fate of agriculture in southern Guinea-Bissau. Journal of Agrarian Change 13: 571-589.

Temudo, M.P.; Abrantes, M. 2014. The cashew frontier in GuineaBissau, West Africa: changing landscapes and livelihoods. Human Ecology 42: 217-230.

Vasconcelos, S.; Mendes, L.F.; Beja, P.; Hodgson, C.J.; Catarino, L. 2014. New records of insect pest species associated with cashew, Anacardium occidentale L. (Anacardiaceae), in GuineaBissau. African Entomology 22: 673-677. 